\title{
The diets of preschool children in Newcastle upon Tyne,
} 1968-71

\author{
By ALISON E: BLACK, W. Z. BILLEWICZ AND A. M. THOMSON \\ MRC Reproduction and Growth Unit, Princess Mary Maternity Hospital, \\ Newcastle upon Tyne $\mathrm{NE}_{2}{ }_{3} \mathrm{BD}$
}

(Received 16 April I975-Accepted 8 May 1975)

\begin{abstract}
1. Ninety-one families containing 140 children under 4 years of age at enrolment were studied. At I-monthly intervals, the children were weighed and measured and qualitative information about feeding habits was obtained. Weighed dietary surveys for periods of $5 \mathrm{~d}$ were made at approximately 8 months, 20 months, 3 years and 5 years of age; there were forty-six failures in 260 surveys attempted.

2. At the four specified ages, mean energy intakes were $3.75,5.03,5.82$ and $6.75 \mathrm{MJ}(896$, 1203,1392 and $16{ }_{3} \mathrm{kcal} / \mathrm{d}$ respectively. At 8 months, milk products provided on average, $43 \%$ of the total energy intake and commercial baby foods provided $17 \%$. These values decreased to $2 \mathrm{I}$ and $2 \%$ respectively at 20 months and there was little further change thereafter.

3. Average intakes of energy and of most nutrients met recommended intakes (Department of Health and Social Security, 1969). Iron intakes were marginal, and vitamin D intakes were low.

4. The energy intake of boys was significantly higher than that of girls at 3 years of age, but the boys were not significantly heavier. The energy intake of children from 'manualworker' families was higher than that from 'non-manual' families. Similarly, the energy intake of children from larger families was higher than that of children from smaller families.

5. Energy intakes were correlated with body-weights and with rates of gain in weight. Irrespective of body-weight, 'big eaters' at 20 months tended to be 'big eaters' at 3 years also.
\end{abstract}

Information on the factors influencing the food intake of children of preschool age (up to 5 years) is somewhat scanty and inconclusive. Furthermore, the situation is liable to change from time-to-time and place-to-place, in response to differences of environment and behaviour.

Previously published information was obtained from surveys of cross-sectional design, each child being studied only once. The present data were collected as part of a semi-longitudinal intensive study, intended primarily to study the relationships between growth and health in a sample of preschool children in Newcastle upon Tyne during the years $1968-7 x$. All the children were under observation at frequent intervals and qualitative information on food patterns during infancy and weaning was obtained. It became possible to measure food intakes at certain key ages, and as many children as possible were studied by dietary survey on as many occasions as possible. This paper reports the dietary findings and their relationships to age, sex, socio-economic status, family size, weight and rate of gain in weight. Although the samples were too small to yield statistically definitive results from all aspects, the findings help to confirm or extend previously published findings (Widdowson, I947; Bransby \& Fothergill, I954; Ministry of Health, 1968). While this paper was in preparation, access was obtained to the report of a more recent study by the Department of Health and Social Security (I975) of a national sample of children of preschool age, and this will be referred to in the Discussion. 
Table I. Ages of preschool children when weighed dietary surveys were made, and number of dietary-survey records obtained

$\begin{array}{lcccccr}\text { Intended age for survey* } & \ldots 8 \text { months } & 20 \text { months } & 3 \text { years } & 5 \text { years } & \text { Total } \\ \text { Mean age } \pm \text { SD (years) } & 0.62 \pm 0.06 & 1.66 \pm 0.09 & 3.07 \pm 0.11 & 4.95 \pm 0.51 & - \\ \text { No. of surveys attempted } & 50 & 73 & 100 & 37 & 260 \\ \text { No. of records not obtained } & \mathrm{I} & 9 & 14 & 9 & 33 \\ \text { No. of records rejected } & 5 & 3 & 3 & 2 & \text { 13 } \\ \text { No. of acceptable records } & 44 & 6 \mathrm{r} & 83 & 26 & 2 \times 4\end{array}$

* These surveys were done whenever possible at 7-8, 19-20, 36-38 and 58-60 months of age.

A preliminary account of the qualitative results has already been published (Black, I97I), and also a description of patterns of weaning and their effects on nutrient intakes at 8 months (Black, 1975). Patterns of weaning from the breast or bottle to a diet of adult type were similar in nearly all individuals, but the timing varied widely. The quantitative records at 8 months of age therefore included some infants who were still being fed mainly on liquid diets, a few were fed mainly on 'solids' and 'paps', and many who were at various intermediate stages.

A separate report on the growth and health of the children will be published elsewhere.

\section{SAMPLE AND METHODS}

Families were recruited from three general medical practices, one in a prosperous residential area and the other two in postwar housing estates. The sample was deliberately biassed to include an excess of families from the upper and the lower ends of the socio-economic spectrum. Children of mixed race and those in one-parent families were excluded, as were those with handicapping congenital defects. Of the families originally approached for the purposes of the growth study, only $4 \%$ failed to cooperate satisfactorily.

For a period of 2 years, ninety-one families, containing 140 children aged under 4 years at enrolment, were asked for further co-operation in intensive dietary studies: all were already co-operating successfully in serial studies of growth and health. Each family was visited at intervals of $\mathrm{I}$ month to weigh and measure the children, and to collect information about health and feeding habits. The methods used for the dietary studies have been described previously (Black, 1973). One-monthly qualitatitive records enabled a picture to be built up of the changing patterns of feeding from early infancy until after complete weaning. These were supplemented by $5 \mathrm{~d}$ weighed dietary surveys (Marr, 1961, 1965), done whenever possible at 7-8, 19-20, 36-38 and $5^{8-60}$ months of age. These ages were chosen to suit the convenience of the families, avoiding times at which other kinds of intensive study were being made. Table I summarizes the numbers of dietary surveys attempted and completed at each age: these ages will be referred to hereafter as 8 months, 20 months, 3 years and 5 years. Twenty children accounted for forty-six failures in 260 surveys attempted; fifty children were surveyed once only, forty-six at two ages, and twenty-four at three ages.

Nutrient values were calculated from food composition tables for individual weighed 
Table 2. Mean energy intakes of preschool children during $5 d$ weighed dietary surveys done at specified ages, and mean percentage of total energy intake derived from various groups of foods

\begin{tabular}{|c|c|c|c|c|}
\hline Approximate age* $\quad \ldots \quad \ldots$ & 8 months & 20 months & 3 years & 5 years \\
\hline No. of children & 44 & $6 \mathrm{I}$ & 83 & 26 \\
\hline Mean energy intakes (MJ (kcal)/d) & $3 \cdot 7(896)$ & $5 \cdot 0(1203)$ & $5 \cdot 8(\mathrm{I} 392)$ & $6.7\left(16 \mathrm{I}_{3}\right)$ \\
\hline \multicolumn{5}{|l|}{ Mean percentage of energy from: } \\
\hline $\begin{array}{l}\text { Commercial baby foods (excluding } \\
\text { cereals) }\end{array}$ & $17 \cdot 0$ & $2 \cdot 2$ & $0 \cdot 2$ & $\circ$ \\
\hline Dried milk & $25 \cdot 6$ & 0.9 & 0.1 & $\circ$ \\
\hline Milk, yoghurt, cream & $17 \cdot 7$ & $20 \% 4$ & $16 \cdot 6$ & $16 \cdot 4$ \\
\hline $\begin{array}{l}\text { Egg, egg dishes, cheese, cheese } \\
\text { dishes }\end{array}$ & $3 \cdot 9$ & $7 \cdot 1$ & $5 \cdot 7$ & $4 \cdot 7$ \\
\hline $\begin{array}{l}\text { Bread, cakes, biscuits, puddings, } \\
\text { tarts }\end{array}$ & II $\cdot 0$ & $25 \cdot 9$ & $28 \cdot 9$ & $3 I \cdot 7$ \\
\hline Breakfast cereals, baby cereals & $6 \cdot 5$ & $5: 2$ & $5 \cdot 6$ & $7 \cdot 3$ \\
\hline $\begin{array}{l}\text { Meat, meat dishes, fish, fish } \\
\text { dishes }\end{array}$ & $2 \cdot 3$ & 10.1 & 10.9 & 10.4 \\
\hline Potatoes, vegetables, fruit & $3 \cdot 8$ & $9 \cdot 3$ & $10 \cdot 3$ & $10 \cdot 4$ \\
\hline Fats & $2 \cdot 0$ & $5 \cdot 6$ & $5 \cdot 8$ & $6 \cdot 3$ \\
\hline $\begin{array}{l}\text { Preserves, cane sugar, confec- } \\
\text { tionery }\end{array}$ & $8 \cdot 8$ & II. & $12 \cdot I$ & $9 \cdot 7$ \\
\hline Sauces, soups, beverages & $I \cdot 4$ & $2 \cdot 5$ & 3.8 & $3 \cdot 2$ \\
\hline Total & 100.0 & $100 \cdot 2$ & 100.0 & $100 \cdot 1$ \\
\hline
\end{tabular}

surveys (Department of Health and Social Security, unpublished results); these were supplemented when necessary by information obtained from the manufacturers of commercial baby foods.

\section{RESULTS}

\section{Food and nutrient intakes and age}

The energy intakes for various foods and groups of foods at each age, expressed as percentages of the total energy supplied, are given in Table 2. At 8 months, milk products provided an average of $43 \%$ of the total energy intake and commercial baby foods (excluding cereals), provided $17 \%$.

By 20 months, most children were sharing the food provided for the family as a whole. Milk now provided $21 \%$ of the total energy intake and commercial baby foods provided only $2 \%$, while cereals and cereal products provided $31 \%$. Between 20 months and 5 years, the proportions changed only slightly.

Table 3 gives the average intakes of energy and nutrients at each age, and standard deviations and quartiles. As expected, intakes varied widely at each age and most distributions were positively skewed. However, since most medians were within $10 \%$ of the mean values (except for ascorbic acid and vitamins $A$ and D) the use of mean values for comparative purposes is not seriously misleading.

Comparisons of the mean intakes with the values recommended by the Department of Health and Social Security (1969) revealed a generally satisfactory situation. For the four age groups, average energy supplies were respectively 98, 100, 93 and $95 \%$ 
108

A. E. Black, W. Z. Billewicz and A. M. Thomson $\quad 1976$

Table 3. Average daily energy and nutrient intakes of preschool children during ${ }_{5} d$ weighed dietary surveys done at specified ages

(Mean values, medians, quartiles $\left(Q_{1}, Q_{3}\right)$ and standard deviations)

\begin{tabular}{|c|c|c|c|c|}
\hline Approximate age* $\ldots$ & 8 months & 20 months & 3 years & 5 years \\
\hline No. of children & 44 & $6 \mathrm{I}$ & 83 & 26 \\
\hline \multicolumn{5}{|l|}{ Energy (kcal) } \\
\hline Mean & 896 & 1203 & 1392 & 1613 \\
\hline Median & 846 & $\operatorname{II} 3^{\circ}$ & 1338 & 1553 \\
\hline$Q_{1}$ & 701 & 973 & 1177 & 1413 \\
\hline$\tilde{Q}_{3}$ & 995 & 1295 & 1477 & 1734 \\
\hline$\widehat{\mathrm{SD}}$ & 276 & $35^{8}$ & 346 & 304 \\
\hline \multicolumn{5}{|l|}{ Energy (MJ) } \\
\hline Mean & 3.75 & 5.03 & $5 \cdot 82$ & $6 \cdot 75$ \\
\hline Median & 3.54 & $4 \cdot 73$ & 5.60 & $6 \cdot 49$ \\
\hline$Q_{1}$ & $2 \cdot 93$ & $4 \cdot 07$ & $4 \cdot 92$ & 5.91 \\
\hline$Q_{3}$ & $4 \cdot 16$ & 5.42 & $6 \cdot 18$ & $7 \cdot 25$ \\
\hline SD & $I \cdot I_{5}$ & $1 \cdot 50$ & $x \cdot 45$ & $1 \cdot 27$ \\
\hline \multicolumn{5}{|l|}{ Total protein $(\mathrm{g})$} \\
\hline Mean & $35 \cdot 2$ & $38 \cdot 1$ & $41 \cdot 4$ & $47 \cdot 4$ \\
\hline Median & $31 \cdot 8$ & $35 \cdot 2$ & $41 \cdot 2$ & $47 \cdot 9$ \\
\hline$Q_{1}$ & $27 \cdot 2$ & 30.9 & 34.0 & $38 \cdot 6$ \\
\hline$\tilde{Q}_{3}$ & $37 \cdot 1$ & $43^{\circ} \circ$ & $48 \cdot 2$ & 57.5 \\
\hline sD & $15 \cdot 6$ & 10.9 & $9 \cdot 6$ & IO'I \\
\hline \multicolumn{5}{|l|}{ Animal protein (g) } \\
\hline Mean & $28 \cdot 4$ & $27 \cdot 8$ & $28 \cdot 2$ & $31 \cdot 5$ \\
\hline Median & $25 \cdot 2$ & $26 \cdot 5$ & $28 \cdot 4$ & $3 \mathbf{I} \cdot \mathbf{I}$ \\
\hline$Q_{1}$ & 19.8 & $22 \cdot 6$ & $22 \cdot I$ & $23 \cdot 7$ \\
\hline$Q_{3}$ & $30 \cdot 8$ & $33 \cdot 0$ & 34.5 & $37 \cdot 3$ \\
\hline SD & 14.2 & $7 \cdot 7$ & $8 \cdot 0$ & $8 \cdot 9$ \\
\hline \multicolumn{5}{|l|}{ Fat (g) } \\
\hline Mean & $37 \cdot 3$ & $54 \cdot 7$ & $6 \pi \cdot 3$ & $69 \cdot 6$ \\
\hline Median & $35 \cdot 2$ & $50 \cdot 8$ & $58 \cdot 6$ & $69 \cdot 2$ \\
\hline $\begin{array}{l}Q_{1} \\
Q_{3}\end{array}$ & $\begin{array}{l}28 \cdot 3 \\
42 \cdot 8\end{array}$ & $\begin{array}{l}42 \cdot 6 \\
60 \cdot 6\end{array}$ & $\begin{array}{l}49 \cdot 2 \\
68 \cdot 2\end{array}$ & $\begin{array}{l}57 \cdot 2 \\
8 \mathrm{I} \cdot 4\end{array}$ \\
\hline SD & $14 \cdot 0$ & 16.7 & 16.7 & $12 \cdot 2$ \\
\hline \multicolumn{5}{|l|}{ Carbohydrate (g) } \\
\hline Mean & III $\times 9$ & $149^{\circ} \mathrm{O}$ & $I 80 \cdot I$ & $212 \cdot 6$ \\
\hline Median & $109 \cdot 6$ & $136 \cdot 4$ & $17 x \cdot 3$ & 205.5 \\
\hline $\begin{array}{l}Q_{1} \\
Q_{3}\end{array}$ & $\begin{array}{r}96 \cdot 8 \\
121 \cdot 2\end{array}$ & $\begin{array}{l}\mathrm{II} 4 \cdot 4 \\
\mathrm{I} 7 \mathrm{I} \cdot \mathrm{I}\end{array}$ & $\begin{array}{l}\mathrm{I} 44.4 \\
208.9\end{array}$ & $\begin{array}{l}174.9 \\
24 I^{\circ} 4\end{array}$ \\
\hline SD & $27 \cdot 9$ & $50 \cdot 3$ & $5 \mathrm{r} \cdot 2$ & $54 \cdot 6$ \\
\hline \multicolumn{5}{|l|}{ Calcium (mg) } \\
\hline Mean & 974 & 705 & 682 & 803 \\
\hline Median & 901 & 673 & 682 & 878 \\
\hline $\begin{array}{l}Q_{1} \\
Q_{3}\end{array}$ & $\begin{array}{r}650 \\
\text { II } 31\end{array}$ & $\begin{array}{l}577 \\
834\end{array}$ & $\begin{array}{l}538 \\
8 \text { II }\end{array}$ & $\begin{array}{l}585 \\
989\end{array}$ \\
\hline SD & 474 & 203 & 183 & 233 \\
\hline \multicolumn{5}{|l|}{ Iron (mg) } \\
\hline Mean & $8 \cdot 77$ & $5 \cdot 83$ & 6.77 & $7 \cdot 97$ \\
\hline Median & $8 \cdot 97$ & $5 \cdot 35$ & $6 \cdot 40$ & $8 \cdot 19$ \\
\hline $\begin{array}{l}Q_{1} \\
Q_{3}\end{array}$ & $\begin{array}{r}5 \cdot 39 \\
11 \cdot 47\end{array}$ & $\begin{array}{l}4 \cdot 12 \\
6 \cdot 30\end{array}$ & $\begin{array}{l}5 \cdot 29 \\
7 \cdot 80\end{array}$ & $\begin{array}{l}6 \cdot 23 \\
9 \cdot 23\end{array}$ \\
\hline SD & $4 \cdot 01$ & $2 \cdot 47$ & $2 \cdot 19$ & $\mathrm{I} .88$ \\
\hline
\end{tabular}


Table 3 (cont.)

Approximate age* ...

8 months

20 months

3 years

5 years

Vitamins:

No. of children

44

$6 \mathrm{I}$

Excluding supplements

Thiamin (mg)

Mean

Median

$Q_{1}$

$Q_{3}$

SD

Riboflavin (mg)

Mean

Median

$Q_{1}$

$Q_{3}$

SD

Ascorbic acid (mg)

Mean

Median

$Q_{1}$

$Q_{3}$

SD

Vitamin A (mg retinol equivalent)

$$
\text { Mean }
$$

Median

$Q_{1}$

$Q_{3}$

SD

0.60

0.56

0.46

0.65

0.27

I 43

I. 34

I.08

1. 65

0.60

32.0

28.7

20.0

$39^{\prime} I$

20.4

o.

0.86

$0.6 \mathrm{I}$

I. 29

0.44

Vitamin $\mathrm{D}$ ( $\mathrm{mg}$ cholecalciferol equivalent)

Mean

Median

8.3

$Q_{1}$

$Q_{3}$

SD

$7 \cdot 4$

$4 \cdot 1$

IO. I

$7 \cdot 0$

Including supplements

Ascorbic acid (mg)

$\begin{array}{ll}\text { Mean } & 43.9 \\ \text { Median } & 37^{\circ} \circ \\ Q_{1} & 29^{\circ} \\ Q_{3} & 53^{\circ} \\ \text { SD } & 24.8\end{array}$

$43 \cdot 9$

$37^{\circ} \circ$

$29^{\circ} 0$

$53 \cdot 8$

$24 \cdot 8$

Vitamin A (mg retinol equivalent)

$\begin{array}{ll}\text { Mean } & I \cdot 08 \\ \text { Median } & 0.9 I \\ Q_{1} & 0.64 \\ Q_{3} & \mathrm{I} \cdot 46 \\ \text { SD } & 0.49\end{array}$

I.08

0.64

0.49

Vitamin D (mg cholecalciferol equivalent)

$\begin{array}{lrr}\text { Mean } & 9 \cdot 2 & 2 \\ \text { Median } & 8 \cdot 0 & \\ Q_{1} & 4 \cdot 4 & 0 \cdot \\ Q_{3} & 12 \cdot 7 & 2 \cdot 6 \\ \text { SD } & 7 \cdot I & 4\end{array}$

0.63

0.58

0.47

0.71

0.33

83

26

$\mathrm{I} \cdot \mathrm{I} 4$

I' 12

0.84

I. 32

0.42

0.72

0.66

0.80

0.51

0.79

0.36

0.77

0.67

0.95

0.20

I 18

I 08

0.88

140

0.49

I. 44

I 40

I. 03

I.76

0.53

$24^{\circ} 9$

$20 \cdot 6$

$14^{-2}$

$33 \cdot 3$

$\times 5.8$

$24^{.} \mathrm{I}$

$2 \mathrm{I} \cdot 2$

14.8

30.0

12.8

$25 \cdot 7$

$25 \cdot 3$

$20 \cdot 1$

$32 \cdot 9$

9.9

0.61

0.64

0.83

0.53

0.41

0.70

0.28

0.48

0.74

0.40

0.68

0.47

0.99

0.49

I 4

I. 0

0.6

I' 5

I. 6

0.43

I 9

I. 4

0.9

I. 7

2.0

I'I

$37^{\circ} \circ$

$28 \cdot 6$

$53 \cdot 8$

36. I

39.4

r 7.8

65.2

$45 \cdot 6$

17.0

$44 \cdot 6$

31.7

25.5

70.1

46.0

0.74

0.75

0.51

0.42

0.94

0.55

0.97

0.80

0.43

0.89

0.46

0.54

I'I 5

0.70

$2 \cdot 7$

$2 \cdot 5$

3'I

$1 \cdot 2$

I' 3

$\mathrm{I} \cdot 5$

0.7
2.6

0.8

$2 \cdot 7$

$3 \cdot 1$

3.6

$4^{\cdot 2}$

For actual mean values see Table $x$. 
of the recommended allowances. Protein, recommended to provide 10 \% of energy intake, provided I 5, I3, I I and I I \% respectively. Animal protein accounted for 8 , 73,68 and $66 \%$ of the total protein intakes respectively.

Average intakes of vitamins and minerals, excluding supplements, were mostly well above requirements, except for iron which was just adequate, and vitamin $\mathrm{D}$ which was low. Supplies of nutrients were most satisfactory at 8 months, due to the high proportion of milk and of fortified dried milks and baby foods in the diet. From 20 months to 5 years increases in average intakes reflected the increasing energy supply. Supplements increased the supplies of ascorbic acid and vitamins A and D for a minority of children; the effects on the mean values for each group were greater than those on the median values.

In the analyses which follow, data for children aged 5 years have been excluded, mainly because of the small size of the sample. Ascorbic acid and vitamins A and D are usually not considered because the ranges of intakes are too wide for differences between groups to be satisfactorily interpreted.

\section{Diets of boys and girls}

At the three selected ages, boys and girls did not differ significantly in body-weight. At 8 and 20 months, boys consumed slightly more energy than girls, but the differences were not statistically significant. At 3 years, the energy intake of boys was significantly greater than that of girls $(P<0.05)$ after making allowance for small differences in body-weight. It is estimated that after allowing for differences of socioeconomic status and family size between each sex category, the energy intake of boys was about $0.42 \mathrm{MJ}$ (100 kcal) more than that of girls.

Nutrient intakes did not indicate any sex-specific patterns, except those associated with the greater energy intake of boys at 3 years of age.

\section{Diets and socio-economic status}

Families were divided into 'manual' and 'non-manual' groups according to the occupations of the fathers; the 'manual' group produced ninety-five dietary surveys for children up to 3 years of age, and the 'non-manual' group produced ninety-three surveys. At all three ages, children of the 'manual' group had a higher average energy intake than those of the 'non-manual' group, the differences being significant $(P<0.05)$ after adjustment, by regression, for differences in body-weight. These differences are difficult to interpret because subgroups, some of which are small, also varied in sex composition, and there was a close association between socio-economic status and family size (see later discussion). After allowing for all these factors it was concluded, tentatively, that the energy intake of children from 'manual' families was on average about $0.54 \mathrm{MJ}$ ( $130 \mathrm{kcal}$ ) higher than that for children from 'non-manual' families, at all three ages.

At 8 months of age, the children of the 'manual' group derived the extra energy almost entirely from dried milk, and for that reason the intakes of total protein, animal protein and calcium were also relatively higher. The children of the 'non-manual' group, however, had a higher average intake of $\mathrm{Fe}$ at 8 months, mainly because most 
of the mothers used commercial baby foods with a relatively high $\mathrm{Fe}$ content and frequently used proprietary dried milks fortified with Fe. At 20 months, socio-economic differentials in the types of food eaten practically disappeared. At 3 years, the 'manual' group made relatively more use of flour and cane sugar products, particularly bread and sweets, and provided their children with less milk. This resulted in a slightly higher intake of carbohydrate and a slightly lower intake of animal protein, $\mathrm{Ca}$ and riboflavin.

\section{Diets and family size}

Comparisons were made between families with one or two children (Fam I, 2) and those with three or more children (Fam $3+)$. Of eighty-nine surveys from the 'Fam I, 2' group (up to 3 years of age), $72 \%$ were from 'non-manual' families, and from ninety-nine surveys in the 'Fam $3+$ ' group, $29 \%$ were from 'non-manual' families. After adjusting for differences in body-weight, children from the larger families were found to have significantly higher energy intakes at all three ages $(P<0.0 \mathrm{I})$ than those from the smaller families. Allowing for differences in the sex and social-class composition of subgroups, as well as in body-weight, it was estimated that children from larger families had an average energy intake which was about $0.67 \mathrm{MJ}$ ( $160 \mathrm{kcal}$ )/d higher than that for children from smaller families.

Differences in food patterns and nutrient intakes were similar to those already described for socio-economic status.

\section{Diet and growth}

In these small samples, there were no significant differences between sexes or social-class groups in body-weights at any given age or rates of gain in weight. However, energy intakes were related to weight; the correlation coefficients were: 8 months, $0.48 ; 20$ months, $0.4 \mathrm{I} ; 3$ years, 0.25 . All three correlations were significant $(P<0.05)$, but with fairly small numbers in each group, we were unable to conclude that the decreasing size of the coefficients with age was meaningful. Weight gains between 6 and 18 months and between 18 months and 3 years were also correlated with energy intakes, defined for this purpose as the average of the intakes measured near the beginning and end of each growth period: the correlation coefficients were 0.37 ( $n 29$, not significant) and $0.36(n 49, P<0.05)$ respectively. On the other hand, energy intakes $/ \mathrm{kg}$ body-weight were not related to either weight or rate of gain in weight.

Most children followed the same 'channel' of growth in weight, especially after the age of 1 year. The pattern of dietary intakes was studied from the records of fortynine children who were surveyed at 20 months and again at 3 years of age. A comparison of ranks, of correlations between pairs of nutrient intakes, and analysis of variance all produced comparable results. The correlation coefficients estimated from the analysis of variance were: energy, $0.54 ; \mathrm{Ca}, 0.32$; ascorbic acid, 0.53 ; vitamin $\mathrm{A}$, 0.26 . All these coefficients were statistically significant $(P<0.05)$.

Allowing for the association between energy and weight $(r 0.4 \mathrm{r}$ at 20 months), the product-moment correlation between energy intakes in the pairs of surveys of 
individual children was 0.59 . This implies that, irrespective of their body-weight status, 'big eaters' at 20 months tended to be 'big eaters' at 3 years also, and vice versa.

The correlations given above indicate that a similar tendency existed for nutrients as for energy.

\section{DISCUSSION}

The pioneer work in this field is that of Widdowson (1947); in a survey of the diets of individual British children, mostly middle-class volunteers, undertaken in 1935-39, I7 I children aged under 5 years were included. She found that boys had a higher energy intake from 3 years of age, but was 'unable to bring to light the laws which relate the height, weight, size and surface area of any one person to his calorie intake'. Bransby \& Fothergill (1954) studied 46I children of preschool age during 1951; they described as 'unexpected' the finding that intakes of energy and nutrients tended to be higher for children belonging to large families and to 'low-income' groups; no anthropometric measurements were made on their subjects. The findings of a pilot study of 434 children, undertaken in 1963 by the Ministry of Health (I 968 ), tended to confirm the findings of Widdowson (1947) and of Bransby \& Fothergill (1954), but differences were small and numbers were 'too small to form a firm basis for policy'. A larger national sample ( 1321 ) of preschool children was studied in 1967 by the Department of Health and Social Security (1975). The results again tended to confirm previous findings, but some doubt remained, because only two-thirds of the families originally sampled yielded usable dietary records. The present data, based on children studied intensively in unusually co-operative families, and including 'serial' as well as 'cross-sectional' evidence, strengthens as well as extends previous conclusions.

Only two specific points appear to require comment. The first is the inverse relationship between energy intake on the one hand and socio-economic status and family size on the other. This finding, taken by itself on the basis of our data, might have been interpreted as an aberration of sampling even though the association was statistically significant. But since the same relationship had been noted by Bransby $\&$ Fothergill (1954) and by the Department of Health and Social Security (1975) it may be accepted as a characteristic of young children in British society. It is not attributable to differences in body-weight, which appears to rule out the idea that children from larger families tend to be overfed. The explanation of the inverse relationship of energy intake to socio-economic status and family size probably lies in differences of energy expenditure, which in turn are more likely to be related to differences in the social environment between families than to biological characteristics of the family members.

Our second comment relates to associations between body-weight, rate of growth in weight and energy intake. Widdowson (1947) and the Department of Health and Social Security (1975) have already found in children of preschool age that energy intake increases with increasing body-weight. Our data suggest that the correlation may become weaker with increasing age, but the numbers are too small to indicate that the trend is statistically significant. If the trend is confirmed by further evidence, the explanation may be that, as age increases, activity becomes increasingly important 
in determining energy intake. Thomson, Billewicz \& Passmore (1961) have pointed out that, in adults, energy intake increases with increasing body-weight much less than would be expected from measurements of energy expenditure during standardized exercise. Our present data also indicate that energy intake in healthy, young children is related to rate of growth in weight, but in the absence of evidence on body composition and energy expenditure we cannot speculate on the meaning of this finding in terms of the sufficiency or otherwise of individual diets for healthy growth. We have, however, shown that 'big eaters' tend to remain 'big eaters', and vice versa. A similar finding was reported by Widdowson ( 1962 ) in the context of dietary survey data obtained from the same children during consecutive weeks and from a few teenagers re-surveyed after about I year, but it has not been previously found in children who are growing rapidly.

The authors are grateful to Drs Catherine Hytten and Mary Fellowes, and to Sister Sheila Coates, who were undertaking the parallel studies of the growth and health of the children; and to the Department of Health and Social Security for letting us see the text of its 1975 report before publication.

\section{REFERENCES}

Black, A. E. (197r). Proc. Nutr. Soc. 3o, 3oA.

Black, A. E. (1973). Nutrition, Lond. 27, 245.

Black, A. E. (1975). Nutrition, Lond. 29, 19.

Bransby, E. R. \& Fothergill, J. E. (1 954). Br. F. Nutr. 8, 195.

Department of Health and Social Security (1969). Rep. publ. Hlth med. Subj., Lond. no. I20.

Department of Health and Social Security (1975). Rep. Hlth Soc. Subj., Lond. no. Io.

Marr, J. W. (1961). Proc. Nutr. Soc. 20, xxxix.

Marr, J. W. (1965). Nutrition, Lond. 19, I8.

Ministry of Health (1968). Rep. publ. Hlth med. Subj., Lond. no. I 18.

Thomson, A. M., Billewicz, W. Z. \& Passmore, R. (196r). Lancet i, 1027.

Widdowson, E. M. (1947). Spec. Rep. Ser. med. Res. Coun. no. 257.

Widdowson, E. M. (1962). Proc. Nutr. Soc. 21, 121. 